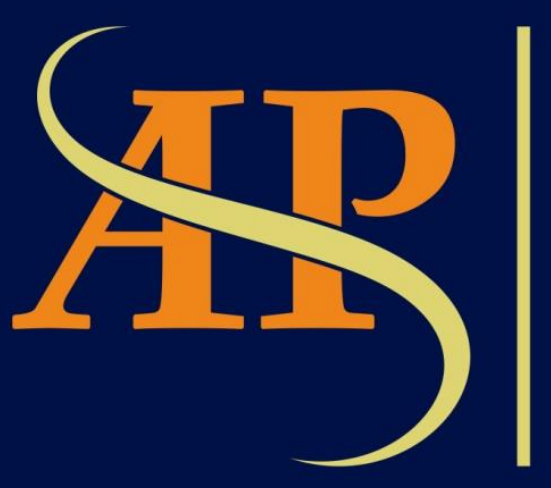

JURNAL

ASIA

PACIFIC

STUDIES

Journal of International Relations Study Program Faculty of Social and Political Sciences

Universitas Kristen Indonesia

Volume 3 | Number 2 | July - December 2019 


\title{
POSTSTRUCTURALISM AND ITS PRACTICAL RELEVANCE IN INTERNATIONAL POLITICS
}

\author{
Rifki Dermawan \\ Department of International Relations, Faculty of Social and Political Sciences, \\ Andalas University, Kampus Limau Manih, Padang, 26115, Indonesia \\ rifkidermawan@soc.unand.ac.id
}

\begin{abstract}
There are many different theories and approaches in international relations studies. They emerge as tools to understand world politics as well as to prevent the occurrence of wars and conflicts. Poststructuralism is one of them. This article addresses the practical relevance of poststructuralism in international politics. It looks at the role of poststructuralism, which provides a novel view on international issues in the globalized era. There are three major focuses of this paper. First, the discussion on the concept of sovereignty and state in a modern world. Second, the role of discourse in the poststructuralism theoretical framework. Third, the function of poststructuralism as a meta-theoretical critique in international relations. This article concludes that poststructuralism is practically useful in the study of international politics.
\end{abstract}

Keywords: poststructuralism, theory, international politics, international relations.

\begin{abstract}
Abstrak
Ada beragam teori dan pendekatan yang digunakan di dalam studi ilmu hubungan internasional. Teori dan pendekatan tersebut muncul sebagai alat untuk memahami kondisi peepolitikan dunia dan juga untuk mencegah terjadinya peperangan dan konflik. Poststrukturalisme adalah salah satunya. Tulisan ini membahas relevansi secara praktikal dari poststrukturalisme dalam politik internasional. Tulisan ini melihat peranan poststrukturalisme yang memberikan pandangan baru terhadap isu-isu internasional di zaman globalisasi. Ada tiga fokus utama dari tulisan ini. Pertama, pembahasan mengenai konsep kedaulatan dan negara di zaman modern. Kedua, peranan wacana dalam kerangka teori poststrukturalisme. Ketiga, fungsi poststrukturalisme sebagai kritik metateori di ilmu hubungan internasional. Kesimpulan yang dapat diambil dari tulisan ini adalah poststrukturalisme memiliki manfaat secara praktikal dalam studipolitik internasional.
\end{abstract}

Kata kunci: poststrukturalisme, teori, politik internasional, ilmu hubungan internasional. 


\section{Introduction}

The development of science occurs based on the need for human beings. As the devastating consequence of the First World War clearly affected people, environment and social life in various places on earth; scholars and experts gathered and established a particular field of study namely international relations (IR). It emerged as the demand to understand the world politics as well as cause and effect of calamitous global conflicts (O'Brien and Williams 2010, 13).

There are plenty of theories and approaches that exist as a response to the appearance of international relations subject area. They give different dimensions to see phenomenon occur in the global level. Each dimension represents a particular theoretical framework in international relations studies (Gold and McGlinchey 2017, 46). Among them, realism has become one of the dominant ideas (O'Brien and Williams 2010, 13). Many kinds of research lay the foundation of their inquiry on this perspective. However, the current circumstance of international politics, which undergoes a lot of changes and evolution has made the root of realism does not fit into this study (Dunne and Schmidt 2006, 177). Looking at this condition, poststructuralism comes into existence as critical approach to IR. It provides different and distinct ways to analyse global issues. One of the main components of poststructuralism is dealing with meta-theoretical questions which inquire about the role of other theories (Campbell 2013, 225). Another concept given by poststructuralism is about interpretation. This is also significant in the analysis of international relations due to the fact that many actors in this field cannot avoid themselves from making interpretation regarding international issues (Campbell 2013, 226).

Generally, the study of international politics has been heavily influenced by the predominant view that is realism. This is proven by the common understanding that a sovereign state has an important position in international politics; which is the primary idea in realism (Dunne and Schmidt 2006, 163). As mentioned in the paragraphs above, the situation in international politics has changed dramatically. It creates a possibility for other actors to have a significant role; for example, the improvement in global economic life makes some companies and firms also possess significant role. Therefore, the state is not the only primary agent in international politics based on this point of view (Waltz 1979, 93-94).

In this paper, I will argue that poststructuralism does not lack practical relevance to the study of international politics because it has a strong correlation as a medium to understand modern global political life. Its analysis started from a question related to the role of state in international politics (Campbell 2013, 226). This is an important point for analysis since the concept of the state as a centre actor is no longer applicable in globalized world, which is different from political phenomena in the past. I personally define the practical relevance of poststructuralism as capability of this approach to analyse events happening in the international relations field. Moreover, poststructuralism also makes an inquiry on the concept of sovereignty. This concept, however, has been questioned in the new era of international politics. It also becomes problematic due to the emergence of powerful non-state actors (Cochran 1995, 241).

This paper consists of three main sections. It starts by analysing the relation between the idea of a sovereign state and current international politics. Then, it continues to discuss the function of discourse - the main tool of poststructural analysis. The last part of the paper will review the importance of meta-theoretical critique offered by poststructuralism. 


\section{Discussion}

\subsection{Decreasing power of a sovereign state in modern international politics}

The capability of the state to exert its authority in particular area defines the concept of sovereignty (Walker 1991, 449). This emphasises the control of the state over anything that happens in its own region, including political activity. The right and responsibility to conduct particular actions lie in the role of the state. It ensures that there is no intervention coming from other agents out of the area, which indicates that a sovereign state is an independent actor. Based on this definition, the state does not need other institutions to deal with its internal problem.

This idea of a sovereign state has become the significant thing in global political sphere from the view of international relations study (Cochran 1995, 240). It acts as a foundation to do analysis regarding issues of international politics. Inquiries about those issues relate to the assumption that the state has its absolute power through sovereignty. The concept of a sovereign state is being recognised as a "truth" in international relations which many poststructuralist scholars try to dispute it.

Nowadays, sovereign state faces an immense problem of doubtfulness since its authority is threatened by the existence of non-state actors (Cochran 1995, 241). There a lot of international organisations actively contribute in terms of relationship among states such as the World Trade Organisation (WTO) and the United Nations (UN). This process, however, will create an intervention in a certain sector which results in decreasing power of state to control its own business. Looking at the concept of sovereignty from international relations point of view, this situation indicates that there is something different with idea of sovereignty in current political world since a state does not have complete power in its area.

The emergence of non-state actors alters the condition of international politics. System of authority and sovereignty has been changed. In addition, the number of international organisations has surged dramatically due to the fact that global society needs institutions capable of embracing international issues from various sectors (Walker 1991, 47). This is the reason why the World Trade Organisation (WTO), World Bank, World Health Organisation (WHO) and United Nations (UN) exist.

As one of the international institutions dealing with global economic activity, WTO has the power to take a part in the relation among states related to trading. Until today, there are 164 countries have decided to be a member of WTO (World Trade Organisation 2017a). It means that the influence of WTO spread all over the world and it is almost impossible for a state to stay away from its effect. Modern international trade is commonly covered under WTO rule. This concept proves that a state with sovereignty is not able to do its activity without the involvement of other actors. In the case of WTO, states will need this international institution when it comes to global trade issues. A state is seen as a powerless agent in the event of a problematic situation between a state and another. The position of WTO actually can be beneficial for states since it assists them in resolving their trading problem or conflict (World Trade Organisation 2017b). The transformation of international relations sphere has challenged the "old concept" of sovereignty because a state needs other actors to work together in a global modern world where sovereignty is not too powerful.

Many changes happen in international politics, as one of the examples is mentioned in the paragraph above regarding international trade and the role of WTO. From years to years, the position and condition of state in international relations transforms to other forms (Milliken 1999, 247). It will not be the same circumstance as in the past. Meanwhile, one of 
the big theories in international relations, realism, made a clear line for the concept of sovereignty (Campbell 2013, 226). Today, that strong definition of sovereignty is getting blurred because of a transformation of international politics. Many states in various areas on earth lose the real concept of the sovereign state due to the fact that their territorial becomes borderless. It indicates that they turn to be more open and they tend to join a regional organisation along with other states, some examples are the European Union (EU) and Association of South East Asia Nation (ASEAN).

In ASEAN, it is obvious that each state has to show respect toward sovereignty of others. This is clearly stated in the fundamental principles of ASEAN (ASEAN no date). However, each state still gets the effect of its membership in ASEAN. Their domestic situation is affected by a decision made in this regional organisation. As ASEAN Economic Community (AEC) 2015 was implemented, economic sector of each member was integrated into one unity (ASEAN no date). The economic condition depends on other countries which can be beneficial or disadvantageous. It shows that state sovereignty is not valid again since a state does not have full control over its activity.

International relations scholars who conduct research on the basis of the main theories of IR will not be able to cover many significant aspects in modern international politics. This happens because those assumptions, such as a sovereign state, undergo a transformation in the global political world. On the other hand, poststructuralism, as a critical approach, emerges and encompasses things marginalised by realism and other dominant views in international relations (Campbell 2013, 226). Poststructuralism comes and gives many insights related to international political issues. It bravely questions those assumptions brought by predominant theories and approaches. This is one of the reasons why I argue that poststructuralism does not lack practical relevance to the study of international politics. Modern international relations researchers need this critical approach to uncover more things because life in international politics is not stagnant and it should not be left behind by scholars. It is interesting to analyse particular problem or issue by utilising new approaches such as poststructuralism. A different view is needed to enrich more understanding about specific field of study. Therefore, poststructuralism is supposed to be one of the essential tools to do research in international relations field.

\subsection{Power of discourse analysis in international politics}

Research on international relations has been conducted through many ways by experts and scholars. In the era of 1990's, discourse analysis gained its popularity among other theories and approaches which is a good thing for an approach that used to be ignored by many scholars (Milliken 1999, 225). It can be an excellent sign for poststructuralism to develop its idea and reveal various hidden things in international political issues. This seems to be the right time for people involving in this field to utilise poststructuralism to be a primary means of analysis.

Poststructuralism as a critical approach mainly uses a different path than other big theories in international relations. It tries to cover something that is not being touched by those prevailing theories (Campbell 2013, 226). Linguistic and cultural values are fundamental in the eye of poststructuralist (O'Brien and Williams 2010, 14). One of the mediums applied by poststructuralist scholars is discourse analysis. Discourse is capable of constructing new meaning which represents a particular idea. Studying discourse will include interpretation which at the end can produce new understanding (Campbell 2013, 234). 
The role of discourse does not only exist in the political field. It has been through many channels, such as mass media and movie. There a lot of research conducted utilising the study of discourse that resulted in interesting findings. It reveals something that is hidden by superficial meaning. One of the examples is a study of Critical Discourse Analysis (CDA) by scholars from the University of Kashan, Iran. This research focuses on a movie about Iranian titled Iranium. The result of this discourse analysis indicates that there is a construction of ideology within the movie which is able to influence the view of audience (Amirian et al. 2012 , 1). It shows that analysis in discourse plays an important role to discuss varied crucial issues because Iran and its own politics has become a hot debate topic among scholars in international relations

The world of discourse also has a dominant side. Apparently, the Western view has strong power to dominate discourse in political issue (Campbell 2013, 226). This, however, is a powerful tool to influence people or scholars involving in international relations studies. It can influence the research and the way people think about certain political phenomenon. A discourse can have great power because it possesses a hidden agenda or meaning that no one can see from the surface. It is something that affects people minds and point of view through a secret channel.

Scholars of poststructuralism believe that discourse acts as a channel to exercise power by the elites. Discourse can be an "unquestionable truth" for society. Poststructuralist argue that most of the international relations theories are not able to explore the "reality" behind discourses (McMorrow 2018). Thus, the emergence of poststructuralism in international relations provides a new point of view on how discourse and power are closely related. It is vital to understand this issue as there is a domination in discourses which leads to domination in power as well.

Poststructuralism along with its discourse analysis will be a helpful tool to reduce Western domination in political discourse. The critical attitude of poststructuralism will be able to uncover plenty of hidden things from issue created by those powerful political actors. This study is getting more relevant since modern international politics also strongly related to popular cultures such as movie, book and mass media. Poststructuralism is needed to provide more perspective and meaning about events occurring all over the globe. This also provides an opportunity for marginalised concept to be heard and recognised by international community.

Language also becomes an essential object of analysis for poststructuralists. Language and discourse are inseparable as language is being used to construct a discourse (McMorrow 2018). The expansion of study into discourse and language shows that poststructuralism involves different aspects in international relations studies. It helps us to understand how power works explicitly through the medium of language which is then created through discourse.

The work of discourse cannot be avoided with the involvement of interpretation. In poststructuralism, interpretation really matters to analyse political issue since it is one of the important ways to conduct research on international relations (Bleiker, in Campbell 2013, 223). This concept of interpretation is relevant to understand modern international politics. It has been discussed in the paragraph above that the Western view dominates most of the discourse in political world. Having an interpretation method as a tool of analysis will assist the scholar in international relations to interpret the meaning behind those discourses. It will provide a new perspective of varied political issues.

Roxanne Lynn Doty in her journal analysed the United States foreign policy using interpretative ways to understand the US action which intervenes Philippine domestic 
problem. She utilises the Cognitive Decision-making Approach, the Social Performance Approach and the Discursive Practices Approach in the analysis (Doty 1993, 297). Her research informs the reader a different view to understand the US-Philippine relationship. She interprets how the US intervention is acceptable in international politics and does not trigger the voice of opposition toward this action. The paper makes it clear about the power of the US to make this intervention as a "normal thing". Without any discourse analysis, it is almost impossible to understand the meaning behind it. This indicates the importance of interpretation in conducting research on international relations. More things can be revealed through the process of interpretation. It ensures that post structuralism along with the power of interpretation is a significant tool to analyze many things occurring in international politics.

Furthermore, post structuralism and its discourse analysis can also contribute to other sectors. The benefit does not only stop at the research level. Obviously, the students and researchers are people who will get more advantage when the study of discourse analysis becomes popular (Milliken 1999, 248). They will have more opportunity to develop their own research. There is a tendency that the result of research can be varied since different perspectives are implemented toward one political problem. This is a good thing for the field of international relations due to the fact that this study is not only limited to the dominant view of international politics. As stated by McMorrow (2018) that "...conventional ways of thinking and analysis in international relations are unable to point out how certain other possibilities are excluded by these discourses...".

Government is also able to utilize discourse analysis for the benefit of the state. Hidden issues uncovered by those international relations scholars can be significant information to make a decision. There will be more perspective for government if it includes the result of research on discourse analysis. This research assists policymakers in government side to have better preparation and understanding before implementing a policy, especially one related to foreign policy issue. Foreign policy needs to be taken seriously and should be seen from various points of view. As an example, it is recommended for government to carefully assess the threat for its own country since it is not a simple thing to consider an issue as a threat in international politics (Campbell 1998, 2). Government should think twice when it comes to make a decision because international politics cannot be seen based on the superficial thing. It contains a lot of hidden meaning, which requires deep interpretation to bring it to the real world. Therefore, post structuralism along with its components, such as discourse language, and interpretation, is a proper approach to do comprehensive research for people working on the international relations field.

\subsection{The importance of meta-theoretical critique}

Discourse and question about the state in international politics are not only the things offered by post structuralism for the study of international relations. There is another significant thing possessed by post structuralism approach namely meta-theoretical critique which makes an inquiry on the existence of other theory (Campbell 2013, 225). This is an interesting thing considering it creates a possibility for many international relations theories to receive critique. Moreover, the situation among international relations theories which is dominated by some views will be better if there is an approach that can critique them. It results in stability within the sphere of international relations study when every single theory or approach is equally appreciated.

The movement of meta-theoretical critique opens the channel for many researchers utilizing post structuralism approach for international relations. In the 1990s, there were a lot 
of studies about international politics with the basis on post structuralism. It gained popularity after the emergence of meta-theoretical critique. Some of them even address crucial issues such as the role of the United Nations, the United States intervention and other securityrelated problems (Campbell 2013, 226). This era shows the power of researchers and scholars in post structuralism view to do analysis on sensitive topics in international politics. However, the result of the research will be useful for experts during that period of time since the analysis with post structuralism has a high probability of being distinguished than other theories or approaches. As international relations study is supposed to focus on how interaction among states works, this is a proper way to open their minds about the international area (O'Brien and Williams 2010, 13).

Meta-theoretical critique brought by post structuralism to the sphere of international politics has a huge advantage for the development of science. Its attitude to critique theories of international relations is on the same track with the purpose of research on social science. The primary idea of conducting research on social science field is to make the object of analysis become understandable for the common audience (Gunnell 2011, 1468). By having more understanding on how a theory or approach work toward a political problem will assist people to have a better understanding. It is an appropriate method to get more knowledge regarding a particular issue. Furthermore, those "marginalized theories" can increase their powerfulness to reveal hidden things along with distinct perspectives. They obviously help people who want to gain information since they are able to provide a wider range point of view in interpretation of world politics. Social science, especially international relations, can be easily understood if there are more theories and approaches are implemented. This should be a right channel for scholars to attain the main goal of social science field.

Science, either natural or social one, will always be developing depends on the circumstance. Even the situation and condition of international politics are changing (Milliken 1999, 247). The emergence of post structuralism is the answer for this transformation currently happening in international relations. Poststructuralist approach does not only have political issue as the focus of the analysis since it also treats the theory as main concern of its research (Campbell 2013, 236). This, however, will be a better improvement in international relations field due to the fact that there is no "the best theory" in any branch of science. I argue that every single theory needs to be challenged and questioned. The capability to conduct an inquiry on those theories is possessed by post structuralism. This is another reason why I argue that post structuralism approach is strongly relevant to the study of international politics.

Besides that, the emergence of post structuralism in IR also opens more opportunities for other theories to be recognized in this study. The basis of post structuralism are close in relevance to other branch of critical thoughts, such as feminist, Marxist, and postcolonial theories in international relations (Edkins 2007, 97). This indicates that post structuralism provides a wider perspective to understand international issues. It is not just being critical but also becomes foundation for other theoretical frameworks. This contribution should be taken into account in terms of developing the study of international relations.

In my analysis, I found that post structuralism approach is having a broader scope of the research than other theories in international relations study. It takes into account the role of other studies, such as linguistic and cultural studies (O'Brien and Williams 2010, 14). Moreover, post structuralism is more flexible and "modern" since a theory is supposed to update on many changes and transformations. For example, popular culture has become an important part of world politics which the study of international relations should focus on this 
matter as well. Finally, post structuralism is one of the approaches capable of taking a clear position among these transformations.

\section{Conclusion}

Many theories and approaches exist in international relations study to help people understand various issues of world politics. Some of them are quite dominant; consequently, the others are being marginalized and their ideas are not recognized by majority of scholars. post structuralism is one of them. Its main concept is coming from different field of studyfocusing on language and culture-which makes many scholars are having a doubt on its relevance to the study of international relations. Fortunately, nowadays post structuralism approach is getting better and able to gain its popularity among researchers.

In this essay, I have attempted to bring the idea that post structuralism is strongly relevant to the study of international politics. The basic question from post structuralism regarding the role of state and sovereignty is a challenge for the dominant theory in international relations, namely realism. This question brings the researcher to the current situation of modern international politics, where a sovereign state concept is no longer applicable. It is an idea offered by post structuralism, which is related to the real situation in world politics today.

Another tool of analysis possessed by post structuralism is the study of discourse. Analysis of discourse provides different points of view to understand political issues. It is beneficial to challenge the domination of some agents in international politics. Moreover, this distinct approach is able to assist government, students and researchers in international relations field to have a deep and distinguishable knowledge. The way post structuralism critiques other theories will also create betterment for the study of international relations and reduce some dominant views. That is why meta-theoretical critique matters in the development of social science. Those novel components owned by post structuralism approach lead to the conclusion that post structuralism does not lack practical relevance to the study of international politics. 


\section{REFERENCES}

\section{Books}

Campbell, D. 1998. Writing Security: United States Foreign Policy and the Politics of Identity, Manchester: Manchester University Press.

Campbell, D. 'Poststructuralism' in Tim Dunne, Milja Kurki and Steve Smith (eds). 2010. International Relations Theories (third edition), Oxford: Oxford University Press

Dunne, T. and Schmidt, B.C. 'Realism' in John Baylis and Steve Smith (eds). 2006. The Globalization of World Politics (third edition), Oxford: Oxford University Press.

Edkins, J. 'Poststructuralism' in Martin Griffiths (eds). 2007. International Relations Theory for Twnety-First Century, Oxon: Routledge.

Gold, D. and McGlinchey, S. 'International Relations Theory' in Stephen McGlinchey (eds). 2017. International Relations, Bristol: E-International Relations Publishing.

O'Brien, R. and Williams, M. 2010. Global Political Economy, Basingstoke: Palgrave Macmillan.

Waltz, K.N. 1979. Theory of International Politics, the United States of America: AddisonWesley Publishing Company.

\section{Journals}

Amirian, M.R., Rahimi, A. and Sami, G. 2012. "A Critical Discourse Analysis of the Images of Iranians in Western Movies: The Case of Iranium." International Journal of Applied Linguistics and English Literature 1 (5): 1-13.

Cochran, M. 1995. "Postmodernism, ethics and international political theory." Review of International Studies 21: 237-250.

Doty, R.L. 1993 "Foreign Policy as Social Construction: A Post-Positivist Analysis of U.S Counterinsurgency Policy in the Philippines." International Studies Quarterly 37 (3): 297-320.

Gunnell, J.G. 2011. "Social Scientific Inquiry and Meta-Theoretical Fantasy: the Case of International Relations." Review of International Studies 37: 1447-1469.

Milliken, J. 1999. "The Study of Discourse in International Relations: A Critique of Research and Methods." European Journal of International Relations 5 (2): 225-254.

Walker, R.B.J. 1991. "State Sovereignty and the Articulation of Political Space/Time." Millennium - Journal of International Studies 20 (8): 445-461.

\section{Websites}

Association of South East Asian Nations. no date. "Overview", accessed 4 January 2017. http://asean.org/asean/about-asean/overview/.

E-International Relations. 2018. "Introducing Poststructuralism in International Relations Theory", accessed 18 November 2019. https $/ /$ www.eir.info/2018/02/13/introducing-poststructuralism-in-international-relations-theory/.

World Trade Organization. 2017a. "What is the WTO?", accessed 1 January 2017. https://www.wto.org/english/thewto_e/whatis_e/whatis_e.htm.

World Trade Organization. 2017b. "Understanding WTO", accessed 2 January 2017. https://www.wto.org/english/thewto_e/whatis_e/who_we_are_e.htm. 